\title{
Anaerobic Digestion of Olive Oil Mill Wastewater Pre-Treated with Catalytic Wet Peroxide Photo-Oxidation Using Copper Supported Pillared Clay Catalysts
}

\author{
R. Ben Achma1', A. Ghorbel', A. Dafinov'2, F. Medina² \\ ${ }^{1}$ Laboratoire de Chimie des Matériaux et Catalyse, Département de Chimie, Faculté des Sciences de Tunis, \\ Tunis, Tunisie \\ ${ }^{2}$ Chemical Engineering Department, University Rovira i Virgili, Tarragona, Spain \\ Email: rymbenachma@yahoo.fr
}

Received April 2014

\begin{abstract}
Because phenolic compounds are toxic for methanogenic bacteria many problems concerning the high toxicity and biodegradability of the olive oil mill wastewater (OMW) have been encountered during anaerobic treatments of this effluent. In this work, we try to develop a new catalytic process for the degradation of phenolic compounds, producing less toxic OMW for methanogenic bacteria, facilitating the anaerobic digestion. This process consists of an oxidative reaction using copper supported on alumina pillared clay in presence of a photocatalytic system $\mathrm{CH}_{2} \mathrm{O}_{2}$ with UV light). Preliminary results showed that the use of the copper supported catalyst in presence of $0.88 \% \mathrm{H}_{2} \mathrm{O}_{2}(\mathrm{v} / \mathrm{v})$ allows after $2 \mathrm{~h}$ colour reduction (25\%), significant abatement of total organic carbon (40\%), and important removal of polyphenolic compounds (63\%) especially those of high molecular mass and subsequently decreases the OMW toxicity from $100 \%$ to $70 \%$. This catalytic pre-treatment process of OMW was efficient for anaerobic digestion.
\end{abstract}

\section{Keywords}

Copper, Pillared Clay, Wet Hydrogen Peroxide Catalytic Oxidation, Anaerobic Digestion

\section{Introduction}

The olive oil industries are an important economic activity of many countries particularly throughout the Mediterranean Sea, with a world production that passes beyond 106 tons/year [1]. However, during olive oil production large quantities of strongly polluted waters, known as olive oil mill wastewaters (OMW), are generated. The seasonal production and high organic loading of OMWs make anaerobic biological treatment a promising alternative and a process of choice for these wastes. Furthermore, this treatment process produces a digested effluent 
with a significant reduction of the organic load and energy (methane) as a valuable end product and may offset the associated treatment costs, further add to the positive aspects of anaerobic treatment. However, the effectiveness of this technology is not always satisfactory because of its highly phytotoxicity and strong antimicrobial properties of OMWs [2]-[4]. Physicochemical treatment processes are also limited by some technical and economical constraints. Recently, the research is focused on original techniques which combine the biological and the physicochemical treatments. Therefore, anaerobic or aerobic biological treatment of these effluents requires a pre-treatment able to eliminate toxic compounds and to increase the biodegradability index. Advanced oxidation methods (AOP) could provide a solution for such environmental problem [5]-[7]. Although the wet air oxydation (WAO) process has demonstrated high effectiveness in the abatement of the organic pollutants [8] [9]. It consists of an oxidation of organic and inorganic compounds in an aqueous solution or suspension by air or oxygen at high temperature and pressure: 423 - $573 \mathrm{~K}$ and 2 - $15 \mathrm{MPa}$ [10]. In order to improve the conditions of such a process, homogenous and heterogeneous catalysts were developed [11]-[13] using strong oxidants such as $\mathrm{H}_{2} \mathrm{O}_{2}$ [14] [15]. The heterogeneous catalysis would be preferred to the homogeneous one if the catalyst is stable in an aqueous medium and selective towards the formation of $\mathrm{CO}_{2}$ and $\mathrm{H}_{2} \mathrm{O}$. Indeed, the biological treatment requires the development of a physicochemical pretreatment process allowing the elimination or the reduction of the amount of toxic compounds e.g. cinamic acid and its derivates. With this general aim in mind, we try to develop a new catalytic process which degrades those phenolic compounds, producing less toxic OMW for methanogenic bacteria, facilitating the anaerobic digestion. This process consists of an oxidative reaction using copper supported on alumina pillared clay in presence of a photocatalytic system $\left(\mathrm{H}_{2} \mathrm{O}_{2}\right.$ with UV light) coupled to biomethanisation. In this context, we have developed in previous work [16] a new methodology of synthesis of rich Cu-supported Al-pillared clay system by solid exchange reaction as catalyst for WHPCO of model pollutant p-Hydroxyphenylethanol (one of the most significant phenols in OMW). This catalyst could be used efficiently in the pretreatment of OMW to reduce toxicity before a biomethanisation treatment.

\section{Experimental Section}

\subsection{Catalyst Preparation and Characterization}

The copper supported Al-pillared clay $\left(\mathrm{Cu}_{5.6} \mathrm{Al}-\mathrm{PILC}(\mathrm{t})\right)$ was prepared by the heterogeneous solid reaction [16]. Quantitative chemical analysis of the copper in the modified clay and physisorption of $\mathrm{N}_{2}$ are carried out as described in [16]. The main characteristics of the catalyst are summarized in Table $\mathbf{1}$.

\subsection{Catalytic Wet Peroxide Photo-Oxidation Tests}

Crude OMW was obtained from a discontinuous olive oil processing plant located in Sfax (southern Tunisia). Fresh dark brown fraction (F3 $<8 \mathrm{kDa}$ ) isolated from OMW by ultrafiltration (Gamma Filtration, France), was first centrifuged (20 min at $4000 \mathrm{rpm}$ ) to remove suspended solids, prior to experiments. The main characteristics of this OMW fraction were illustrated in Table 2.

Oxidation experiments were carried out in batch mode using a stirred Pyrex well mixed slurry reactor of 100 $\mathrm{ml} .80 \mathrm{~mL}$ of freshly fraction $\left(\mathrm{F} 3<8 \mathrm{kDa}\right.$ ) was introduced to the reactor together with $0.5 \mathrm{~g} . \mathrm{L}^{-1}$ of the catalyst $\left(\mathrm{Cu}_{5.6} \mathrm{Al}-\mathrm{PILC}(\mathrm{t})\right)$ and varied concentrations of $\mathrm{H}_{2} \mathrm{O}_{2}$, ranging from $0.8 \%$ to $4.4 \%(\mathrm{~V} / \mathrm{V})$. This mixture was, finally, incubated for $24 \mathrm{~h}$ without any contact with the air atmosphere and at $298 \mathrm{~K}$, in the presence of UV radiation $(366 \mathrm{~nm}$ ). Irradiation was carried out with $30 \mathrm{~W}$ UV-lamp (APLEX, France), which was put above the flasks. The distance between solution and UV source was constant, $15 \mathrm{~cm}$ in all experiments. Reaction tests were carried out at the $\mathrm{pH}$ of the initial OMW fraction. Samples were withdrawn every $2 \mathrm{~h}$ and analysed after being centrifuged at $3500 \mathrm{rpm}$ for $10 \mathrm{~min}$ to remove completely catalyst particles. The efficiency of the photocatalytic tests was estimated by the follow-up of the Colour Number, HPLC analysis (SE and C18), total polyphenols abatement, TOC measurement and toxicity tests.

\subsection{Anaerobic Digestion and Biogas Analysis}

Anaerobic digestion tests were applied to both raw and pre-treated samples for comparison purpose. Two anaerobic filters (AFs) were used in this study. These reactors were made of a glass column having a working volume of $3 \mathrm{~L}$. The inner tubes were enclosed in a jacket through which hot water circulated to maintain 
Table 1. Textural properties and copper content of the $\mathrm{Cu}_{5.6} \mathrm{Al}-\mathrm{PILC}(\mathrm{t})$ catalyst.

\begin{tabular}{cc}
\hline Property & Value \\
\hline $\mathrm{S}_{\mathrm{BET}}\left(\mathrm{m}^{2} / \mathrm{g}\right)$ & 197 \\
$\mathrm{~V}_{\mathrm{p}}\left(\mathrm{cm}^{3} / \mathrm{g}\right)$ & 0.128 \\
$\mathrm{~V}_{\mu \mathrm{p}}\left(\mathrm{cm}^{3} / \mathrm{g}\right)$ & 0.081 \\
$\mathrm{~d}_{001}(\mathrm{~nm})$ & 1.78 \\
$\mathrm{Cu}(\mathrm{wt} . \%)$ & 4.70 \\
\hline
\end{tabular}

Total surface area obtained from the BET equation $\left(\mathrm{S}_{\mathrm{BET}}\right)$, Micropore volume obtained from the t-plot method $\left(\mathrm{V}_{\mu \mathrm{p}}\right)$, and the total pore volume at $\mathrm{P} / \mathrm{P} 0=0.99(\mathrm{VP})$.

Table 2. Characterisation of isolated F3 fraction.

\begin{tabular}{cc}
\hline Parameters & F3 $<8 \mathrm{kDa}$ \\
\hline pH & 4.8 \\
Soluble COD $\left(\mathrm{g} \cdot \mathrm{l}^{-1}\right)$ & 28.9 \\
COD/BOD5 & 4.92 \\
Total polyphenols $\left(\mathrm{g} \cdot \mathrm{l}^{-1}\right)$ & 1.69 \\
CN $\left(\mathrm{m}^{-1}\right)$ & 257.75 \\
IB $(\%)$ & 100 \\
\hline
\end{tabular}

the temperature of the filter at $37^{\circ} \mathrm{C}$. These anaerobic filters was packed with polyurethane foam cubes $2 \mathrm{~cm}$ $\times 2 \mathrm{~cm} \times 1 \mathrm{~cm}$ (Filtren T45, from Recticel, Wetteren, Belgium) as support and inoculated with an 8-year-old digester operated with untreated or WHPCO pre-treated OMW F3 fraction (the pH was adjusted to 7.5 with calcium bicarbonate). The influent was fed in six times into the reactor using a pump connected to a programmer. Gas samples were taken with a syringe from the tank of biogas. $\mathrm{CH}_{4}, \mathrm{CO}_{2}$ and $\mathrm{N}_{2}$ were measured using a gas chromatograph GC11 (Delsi instruments) equipped with a Haye SepQ 60/80 (SUPELCO) column (maintained at $60^{\circ} \mathrm{C}$ ), a thermal conductivity detector (current intensity of $160 \mathrm{~mA}$ ) and a servotrace integrator (SEFRAM). Helium was used as a carrier gas at a pressure of 1.3 bars.

\subsection{Analytical Methods.}

HPLC analysis used for monomeric phenols was performed on a Shimadzu apparatus composed of an LC-10ATvp pump and an SPD-10Avp detector. The column was a C-18 $(4.6 \mathrm{~mm} \times 250 \mathrm{~mm}$; Shimpack VPODS), and its temperature was maintained at $40^{\circ} \mathrm{C}$. The flow rate was $0.5 \mathrm{~mL} \cdot \mathrm{min}^{-1}$. The mobile phase used was $0.1 \%$ phosphoric acid in water (A) versus $70 \%$ acetonitrile in water (B) for a total running time of 50 min and the following proportions of solvent B were used for the elution: 0 - $30 \mathrm{~min}, 20 \%-50 \%$; $30 \%-35 \mathrm{~min}, 50 \%$; and 35 - $50 \mathrm{~min}, 50 \%-20 \%$. The flow rate was $0.6 \mathrm{~mL} \cdot \mathrm{min}^{-1}$, and the injection volume was $20 \mu \mathrm{L}$ [17].

Concentration of high-molecular-mass polyphenol compounds was determined a Progel TSK-G 2000-SW. Supelco column $(300 \mathrm{~mm} \times 7.8 \mathrm{~mm}$ ) was used with a Shimadzu 10Avp apparatus to analyze. The elution was carried out using a phosphate buffer $\mathrm{pH} 6.8$ and $0.6 \mathrm{~mL}$ min-1 flow rate. The wavelength of the detector was adjusted to $280 \mathrm{~nm}$. TOC was determined using a 5050A Shimadzu model carbon analyser.

COD was determined according to Knechtel standard method [18].

The colour is measured at the two characteristic wavelengths of OMW 395 and $495 \mathrm{~nm}$. The colour is given by the spectral absorption coefficient (SAC) [19]. SAC can be measured by the absorption $\mathrm{E}$ in a cuvette with a layer $\mathrm{x}$ at the mentioned wavelength by SAC $=E / x$;

For practical handing, Dopkens et al. [20] defined the colour number CN which is characterized by the weighted average of the SAC. It can be calculated by 


$$
\mathrm{CN}=\left(S A C_{395}^{2}+S A C_{495}^{2}\right) /\left(S_{39 C_{39}}+S A C_{495}\right)
$$

with the spectral absorption coefficients $\mathrm{SAC}_{395}$ and $\mathrm{SAC}_{495}$ at 395 and $495 \mathrm{~nm}$ respectively.

The microtoxicity test consists of the inhibition of the bioluminescence of Vibrio fischeri LCK480 using the (Dr Lange GmbH, Düsseldorf, Germany) Lumistox system and according to ISO 11348-2 [21]. Percentage inhibition of the bioluminescence was achieved by mixing $0.5 \mathrm{~mL}$ of OMW F3 fraction and $0.5 \mathrm{~mL}$ luminescent bacterial suspension. After 15 minute exposure at $15^{\circ} \mathrm{C}$, the decrease in light emission was measured. The toxicity of the sample is expressed as the percent of the inhibition of bioluminescence (\%IB) relative to a non-contaminated reference. A positive control $(7.5 \% \mathrm{NaCl})$ was included for each test.

\section{Results and Discussion}

\subsection{WHPCO Treatment of OMW F3 Fraction}

As the low molecular-mass phenolics are deemed to be the highly toxic products of OMW, our investigations are focused on the determination of the performance of WHPCO in decreasing their acute toxicity. Thus, preliminary photocatalytic experiments were undergone on real low molecular mass phenolic toxic fraction F3 (IB $=100 \%$ ). The ethyl acetate extract of this low molecular-mass fraction, analyzed by HPLC (Figure 1) shows that hydroxytyrosol occurs for more than $50 \%$ of the ethyl acetate extractable compounds. 3,4-dihydroxyphenylacetic acid, tyrosol, vanillic acid, p-coumaric acid, ferulic acid and some flavonoids are also present.

Figure 2 shows the evolution of colouration, monomers removal, hydroxytyrosol conversion, total phenol and total organic carbon (TOC) removal. Obtained results showed that decolorization of the effluent was obtained only after $12 \mathrm{~h}$ for all the tested $\mathrm{H}_{2} \mathrm{O}_{2}$ concentration. This could be explained by the fact that some coloured low molecular mass polyphenols such as condensed tannins could be more resistant to the catalytic system used in our study. While, HPLC analysis showed the removal of the major monomeric compounds detected in the F3 fraction which resulted in decreasing the toxicity from $100 \%$ to $74 \%$ after $2 \mathrm{~h}$ and up to $26 \%$ after $24 \mathrm{~h}$ treatment (Figure 3) and this is consistent with the reduced concentration of total phenols recorded (Figure 2(d)). Indeed, after $2 \mathrm{~h}$ treatment the polyphenolic compounds conversion is about $60 \%$ for $0.88 \mathrm{H}_{2} \mathrm{O}_{2}$ concentration. A removal of about $93 \%$ is obtained for the hydroxytyrosol, the major ortho-diphenol, treated with $0.88 \% \mathrm{H}_{2} \mathrm{O}_{2}$ during $2 \mathrm{~h}$. The TOC abatement was $60 \%$ after $24 \mathrm{~h}$ treatment even with high $\mathrm{H}_{2} \mathrm{O}_{2}$ concentration (data not shown), indicating a preferential reduction of these toxic compounds with respect to TOC abatement in agreement with the objective to reduce the toxicity, to improve biodegradability and to minimize as much as possible the TOC reduction.

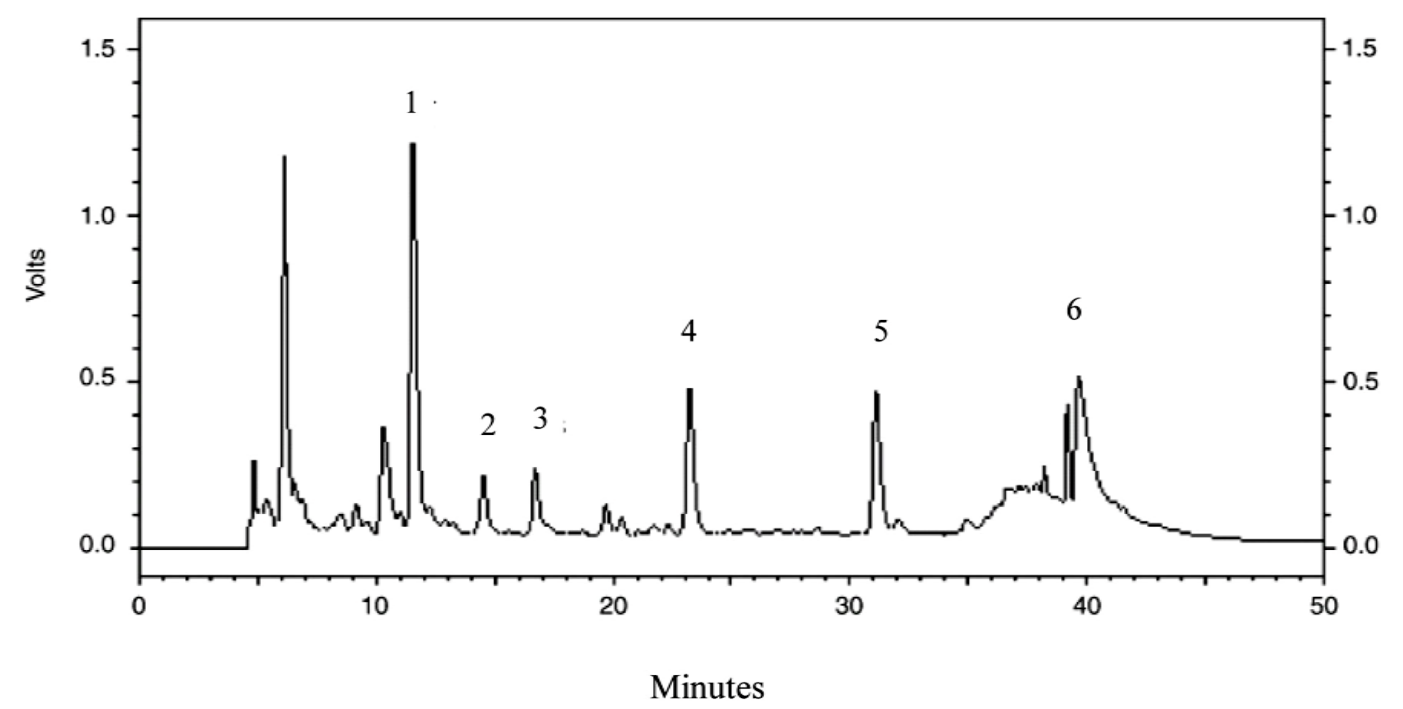

Figure 1. C18-HPLC chromatogram of phenolic compounds presentin OMW F3 fraction. 1: hydroxytyrosol; 2: 3,4 dihydroxyphenylacetic acid; 3: tyrosol; 4: vanillic acid; 5: $p$-coumaric acid; 6: ferulic acid. 

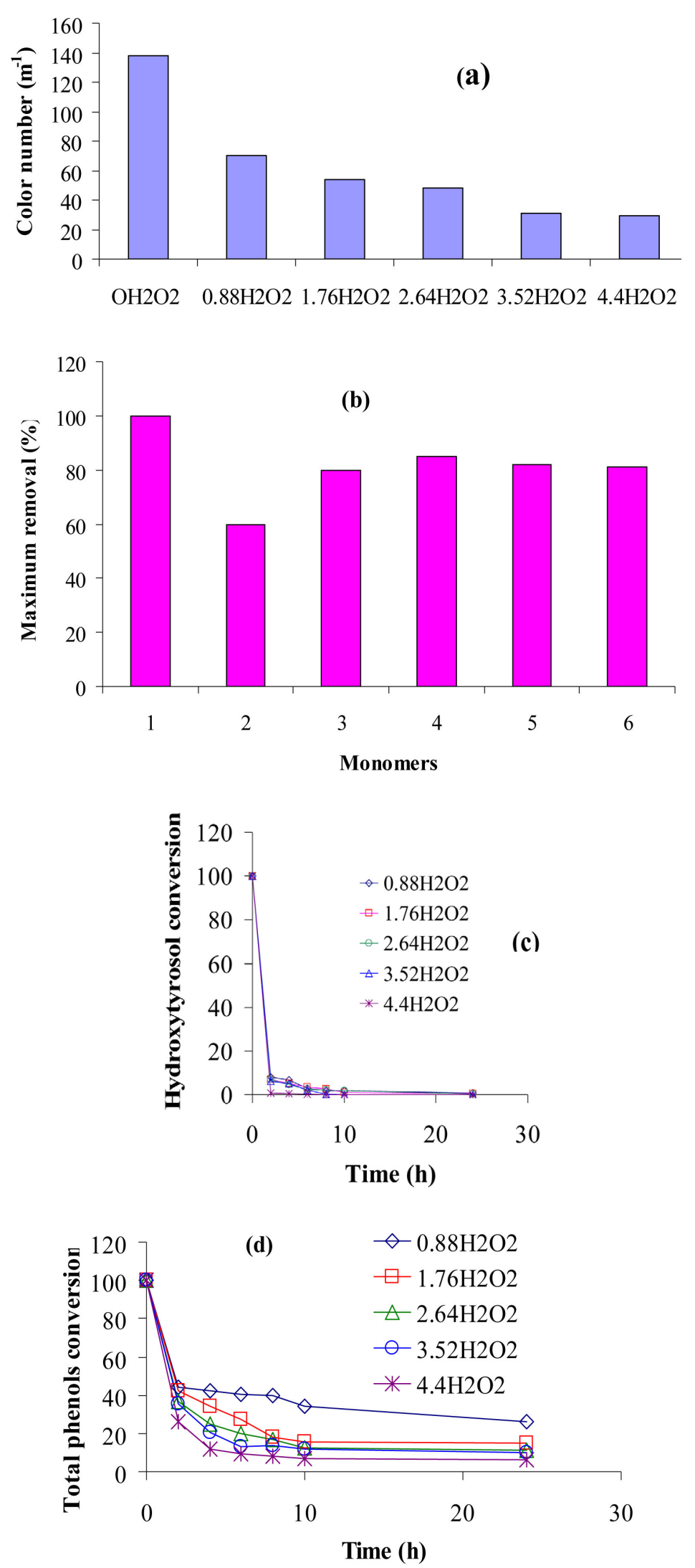


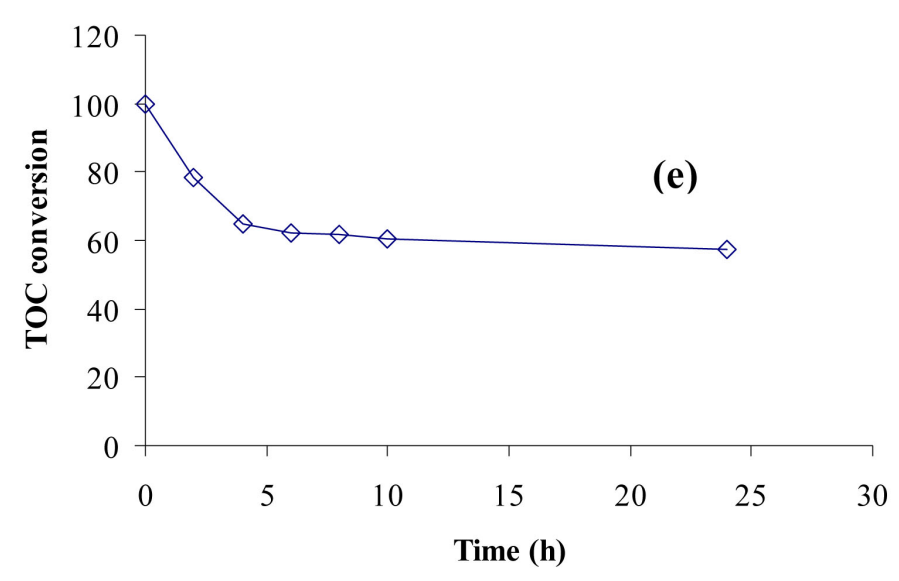

Figure 2. Colour reduction (a), monomer removal (b), Hydroxytyrosol conversion (c), Total phenols conversion (d) and TOC removal (e).

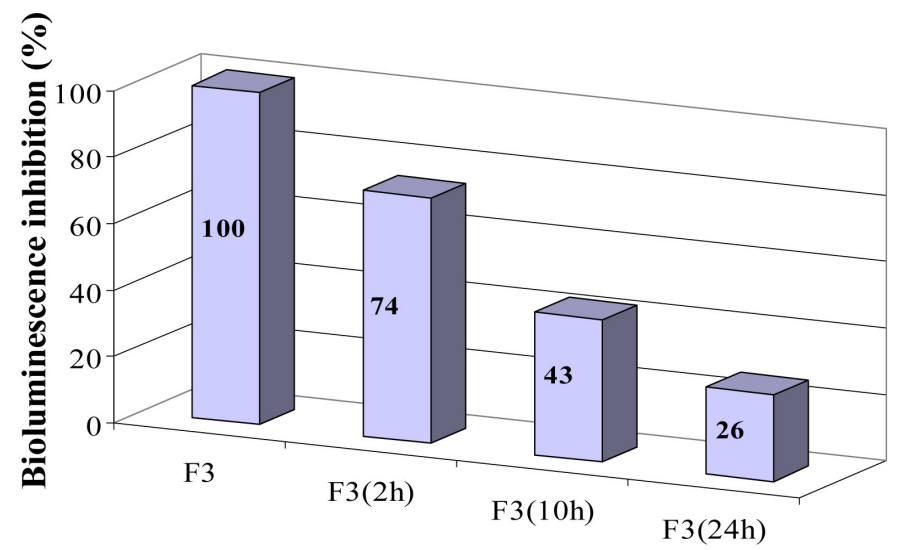

Figure 3. The relative toxicity using V.fischeri test of samples drawn prior to and after WHPCO treatment of F3 at $2 \mathrm{~h}, 10 \mathrm{~h}$ and $24 \mathrm{~h}$.

Since, the catalytic treatment is associated to a methanization process; the aim of these experiences is to reduce the TOC and not its complete removal. Then a treatment with $0.88 \% \mathrm{H}_{2} \mathrm{O}_{2}$ during $2 \mathrm{~h}$ can be adopted because it allowed a TOC abatement of $40 \%$ (Figure 2(e)). The phenolic polymer evolution during the cat alytic treatment is illustrated by Figure 2(d). It is important to note that this catalytic treatment is more significant with the high molecular mass polyphenols (as monitored by Size Exclusion-HPLC using the Progel.

TSK-G 2000-SW Supelco column) than with the monomer one. Indeed, Figure 2(d) shows that, after $2 \mathrm{~h}$ reaction, important concentrations of the polyphenols were removed with concomitant colour reduction (Figure 2(a)). The toxicity of untreated OMW and 2 and $24 \mathrm{~h}$ treatments revealed a significant detoxification (Figure 3). According to the previous results we can conclude that the treatment of the OMW F3 fraction by $\mathrm{H}_{2} \mathrm{O}_{2}$ catalytic oxidation allowed a significant detoxification by decreasing the organic charge (TOC) and the phenol concentration. Then an oxidative treatment with $0.88 \% \mathrm{H}_{2} \mathrm{O}_{2}$, under UV (366 nm), during $2 \mathrm{~h}$ and in presence of $0.5 \mathrm{~g} \cdot \mathrm{L}^{-1}$ of $\mathrm{Cu}_{5.6} \mathrm{Al}-\mathrm{PILC}(\mathrm{t})$ catalyst is adopted in order to test the effect of such treatment on OMW methanization.

\subsection{Anaerobic Digestion of Both Raw and Pre-Treated OMW F3 Fraction}

\subsubsection{Anaerobic Digestion of OMW}

Difficulties met in the anaerobic treatment of olive mill effluents suggest the use of a physico-chemical pretreatment for the removal of bio-recalcitrant and/or inhibiting substances (essentially lipids and polyphenols) as 
selectively as possible before anaerobic digestion. The anaerobic digestion of raw OMW was performed in a $3 \mathrm{~L}$ anaerobic filter reactor. The yield of methanisation of this crude diluted OMW was higher than $0.25 \mathrm{~L} \cdot \mathrm{CH}_{4} \cdot \mathrm{g}^{-1}$ COD introduced at low loading rates. However, since the 20th day, when the loading rate reached a mean of 4 $\mathrm{g}^{-1} \cdot \mathrm{L} \cdot \mathrm{d}^{-1}$ of COD, a decrease in the biogas yield was observed (Figure $4 \mathbf{b}(\mathbf{R})$ ). This test will serve as control for comparing the efficiency of the WHPCO pre-treatment in the detoxification of this effluent.

\subsubsection{Anaerobic Digestion of WHPCO Pre-Treated OMW}

The anaerobic filter was loaded with undiluted WHPCO pre-treated OMW at a starting loading rate of $2 \mathrm{~g}$ COD $\mathrm{L}^{-1} \cdot \mathrm{d}^{-1}$. The evolution of the loading rate, biogas productivity, methane yield and are presented in Figure $\mathbf{4}(\mathbf{T})$. During the fermentation of WHPCO pre-treated OMW, the biogas productivity and methane yield increased with increased loading rate (Figure $\mathbf{4}(\mathrm{T})$ ). The volume of biogas reached $14 \mathrm{~L}$ per day for a loading rate of $8 \mathrm{~g}$ of COD introduced. The higher values of methane yields $\left(0.36-0.38 \mathrm{~L}^{\circ} \mathrm{CH}_{4} \cdot \mathrm{g}^{-1} \mathrm{COD}\right.$ introduced) were also obtained for this loading rate. The COD was reduced to $5 \mathrm{~g} \cdot \mathrm{L}^{-1}$, reaching $95 \%$ of COD removal (data not shown). But when the organic loading increase from 4 to $8 \mathrm{~g} \mathrm{COD} \mathrm{L}^{-1} \cdot \mathrm{d}^{-1}$, the percentage of COD removal decrease to $85 \%$. This could be due to the high COD concentration of OMW used $\left(40 \mathrm{~g} \cdot \mathrm{L}^{-1}\right)$.

Indeed, the WHPCO pre-treated OMW was not diluted prior to feeding in the anaerobic filter. In addition, relatively high concentrations of phenols are introduced in the batch and it's possible that, using this loading rate, part of this organics (probably high molecular mass polyphenols) are unable to be degraded by anaerobic
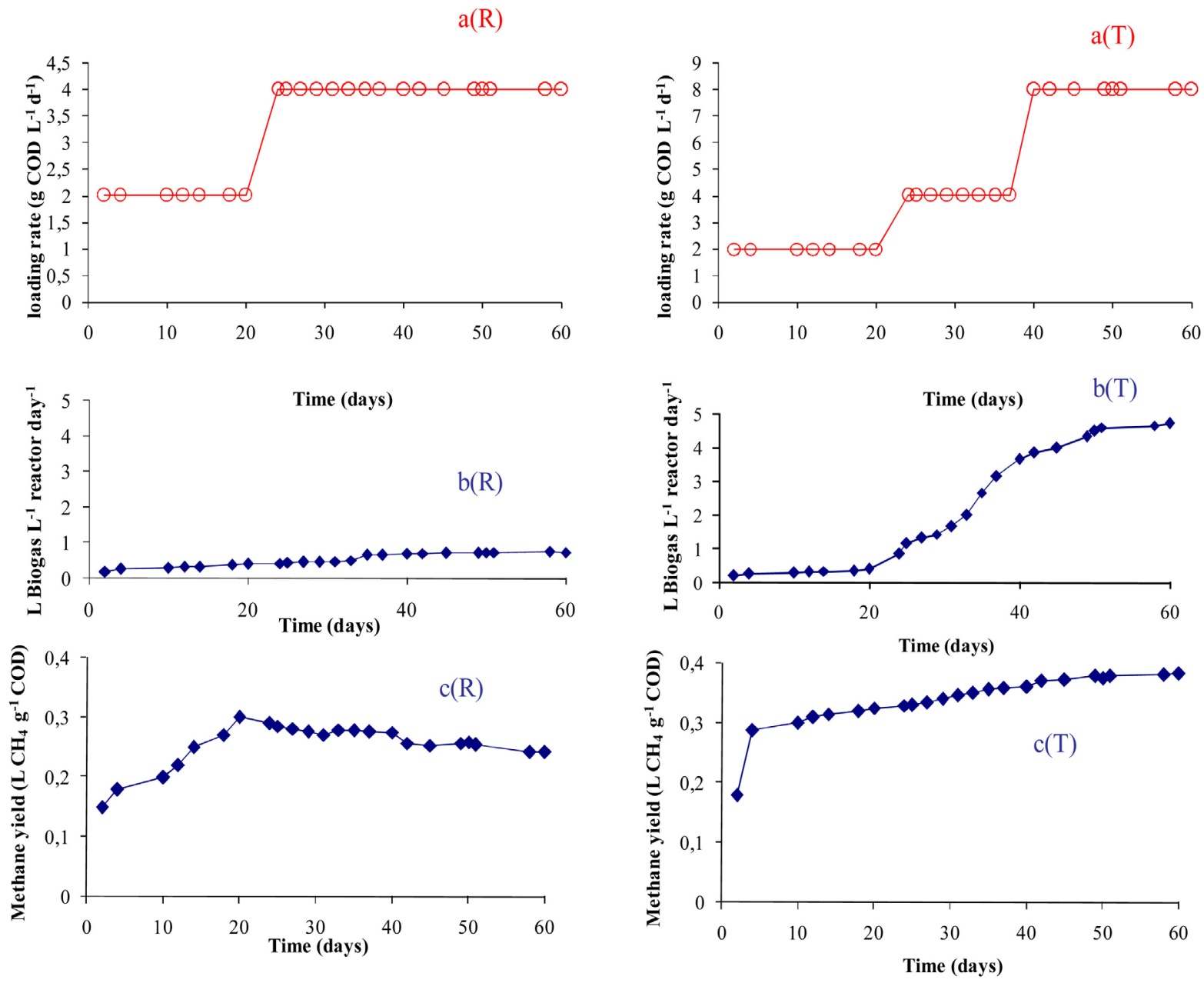

Figure 4. Evolution of the loading rate $\left(\mathrm{g} \cdot \mathrm{COD} \cdot \mathrm{L}^{1} \cdot\right.$ reactor $\left.\cdot \mathrm{d}^{-1}\right)(\mathrm{a})$, biogas production $\left(\mathrm{L}^{-\mathrm{L}^{-1}}\right)$ (b) and methane yield $\left(\mathrm{L} \cdot \mathrm{CH}_{4} \cdot \mathrm{g}^{-1} \mathrm{COD}\right.$ introduced) (c) during anaerobic digestion of raw OMW (R) and WHPCO treated OMW (T). 
digestion. However, organics which were degraded by anaerobic bacteria were transformed mainly to methane. Knowing that untreated OMW causes inhibition of methanisation at a loading rate $2-4 \mathrm{~g} \mathrm{COD} \cdot \mathrm{L}^{-1} \cdot \mathrm{d}^{-1}[22]$, we can conclude that WHPCO of crude OMW resulted in decreasing the toxic effect of this effluent on anaerobic digestion.

\subsection{Conclusion}

The catalytic wet hydrogen peroxide oxidation using $\mathrm{Cu}_{5.6} \mathrm{Al}$-PILC(t) catalyst applied on crude OMW as pre-treatment resulted in removing a large amount of recalcitrant polyphenolic compounds as well as it allowed a significant detoxification by decreasing the organic charge (TOC).

The anaerobic process applied as post-treatment reached a loading rate of $8 \mathrm{~g} \mathrm{COD} \mathrm{L}{ }^{-1} \cdot \mathrm{d}^{-1}$ without any apparent toxicity.

\section{Acknowledgements}

The authors are grateful to the AECI ref. A/5927/06 Project from the Ministerio de Asuntos Exteriores y Cooperacion de España and the Tunisian Ministry of High Education, Scientific Research and Technology.

\section{References}

[1] Bureau, R., Borja, C.J., Banks, A. and Garrido, A. (1994) Kinetics of Black-Olive Wastewater Treatment by the Activated- Sludge System. Process Biochemistry, 29, 587-593. http://dx.doi.org/10.1016/0032-9592(94)80023-5

[2] Borja, R., Martin, A., Alonso, V., Garcia, I. and Banks, C. (1995) Influence of Different Aerobic Treatment on the Kinetics of Anaerobic Digestion of Olive Oil Mill Wastewater (Alpechin) and Its Sludge for Agricultural Purposes. Water Research, 29, 489-495. http://dx.doi.org/10.1016/0043-1354(94)00180-F

[3] Hamdi, M., Festino, C. and Aubart, C. (1992) Anaerobic Digestion of Olive Mill Wastewaters in Fixed Film Reactors. Process Biochemistry, 27, 37-42. http://dx.doi.org/10.1016/0032-9592(92)80007-P

[4] Beccari, M., Majone, M. and Torrisi, L. (1998) Two Reactor System with Partial Phase Separation for Anaerobic Treatment of Olive Mill Effluents. Water Science and Technology, 38, 53-60. http://dx.doi.org/10.1016/S0273-1223(98)00497-1

[5] Herrera, F., Pulgarin, C., Nadtochenko, V. and Kiwi, J. (1998) Applied Catalysis B: Environmental, $17,141$. http://dx.doi.org/10.1016/S0926-3373(98)00008-3

[6] Andreozzi, R., Caprio, V., Insola, A. and Marotta, R. (1999) Catalysis Today, 53, 51. http://dx.doi.org/10.1016/S0920-5861(99)00102-9

[7] Mantzavinos, D., Hellenbrand, R., Livingston, A.G. and Metcalfe, I.S. (1997) Water Science and Technology, 35, 119. http://dx.doi.org/10.1016/S0273-1223(97)00017-6

[8] Luck, F. (1999) Catalysis Today, 53, 81. http://dx.doi.org/10.1016/S0920-5861(99)00112-1

[9] Kolaczkowski, S.T., Plucinski, P., Beltran, F.J., Rivas, F.J. and McLurgh, D.B. (1999) Chemical Engineering Journal, 73, 143. http://dx.doi.org/10.1016/S1385-8947(99)00022-4

[10] Lin, S.H. and Ho, S.J. (1996) Catalytic Wet-Air Oxidation of High Strength Industrial Wastewater. Applied Catalysis B: Environmental, 9, 133-147. http://dx.doi.org/10.1016/0926-3373(96)90077-6

[11] Imamura, S. (1999) Catalytic and Non-Catalytic Wet Oxidation. Industrial \& Engineering Chemistry Research, 38, 1743-1753. http://dx.doi.org/10.1021/ie980576l

[12] Luck, F. (1999) Wet Air Oxidation: Past, Present and Future. Catalysis Today, 53, 81-91. http://dx.doi.org/10.1016/S0920-5861(99)00112-1

[13] Hamoudi, S., Larachi, F. and Sayari, A. (1998) Wet Oxidation of Phenolic Solutions over Heterogeneous Catalysts: Degradation Profile and Catalyst Behavior. Journal of Catalysis, 177, 247-258. http://dx.doi.org/10.1006/jcat.1998.2125

[14] Netti, S. and Wlassics, I. (1995) Riv. It. Sost. Grasse, 72, 119.

[15] Bauer, R., Waldner, G., Fallmann, H., Hager, S., Klare, M., Krutzler, T., Malato, S. and Aletzky, P. (1999) Catalysis Today, 53, 131. http://dx.doi.org/10.1016/S0920-5861(99)00108-X

[16] Achma, R.B., Ghorbel, A., Dafinov, A. and Medina, F. (2012) Synthesis of Stable Cu-Supported Pillared Clays for Wet Tyrosol Oxidation with $\mathrm{H}_{2} \mathrm{O}_{2}$. Journal of Physics and Chemistry of Solids, 73, 1524-1529. http://dx.doi.org/10.1016/j.jpcs.2012.04.010 
[17] Miranda, M.A., Galindo, F., Amat, A.M. and Arques, A. (2001) Applied Catalysis B: Environmental, 30, 437. http://dx.doi.org/10.1016/S0926-3373(00)00259-9

[18] Knechtel, R.J. (1978) J. Water Pollut. Control Fed., 25.

[19] Working Group Textile Production and Finishing Industry (1999) Abwassertechnische Vereinigung, Zur Farbigkeit von Abwasser der Textilveredelungsindustir, Work Report. ATV, Hennef.

[20] Dopkens, E., Jonas, R., Jung, T., Krull, R. (2001) Colloqium Produktionsintegrierte Wasser/Abwassertechnik, Nachhaltige Produktion in der Textilverdelung und Membrantechnik. Bremen, 143.

[21] ISO 11348-2 (1998) Water Quality-Determination of the Inhibitory Effect of Water Samples on the Light Emission of Vibrio Fischeri (Luminescent Bacteria Test)-Part 2: Method Using Liquid-Dried Bacteria.

[22] Kang, S.F. and Chang, H.M. (1997) Coagulation of Textile Secondary Effluents with Fenton's Reagent. Water Science and Technology, 36, 215-222. http://dx.doi.org/10.1016/S0273-1223(97)00707-5 